УДК 37.014.3:37.014.53

\begin{abstract}
Наталія Лісова,
кандидат педагогічних наук, дочент кафедри педагогіки та менеджменту КНЗ «Черкаський обласний інститут післядипломної освіти педагогічних прачівників», м. Черкаси
\end{abstract}

\title{
ФЕНОМЕН МЕХАНІЗМІВ ДЕРЖАВНО-ГРОМАДСЬКОГО УПРАВЛІННЯ РОЗВИТКОМ ЗАГАЛЬНОЇ СЕРЕДНЬОЇ ОСВІТИ
}

У статті звернено увагу на трансформацуійні процеси, які відбуваються в системі загальної середньої освіти й управлінні нею та детермінують характер зміни изілей, завдань, функиій $i$ самої форми управління. Подано аналіз досліджень, у яких вчені розглядають механізми управління системою освіти, зокрема наголошують на пріоритетному значенні механізмів державно-громадського управління загальною середньою освітою. Розглянуто механізми державно-громадського управління та місчевого самоврядування відділу освіти, функиї якого здійснюються в різних умовах малих міст Украӥни (міст обласного та районного значення, міських ОТГ), подано термінологічний аналіз частоти звернень користувачів мережі Інтернет до основних понять обраної теми; розглянуто феномен державно-громадського управління розвитком загальної середньої освіти.

Ключові слова: управління, механізм, місчеве самоврядування, феномен, малі міста, відділ освіти, довіра.

Attention is paid to the transformational processes taking place in the system of general secondary education and its management and determine the nature of the change of objectives, tasks, functions and the very form of management. The analysis of researches in which scientists consider mechanisms of management of the education system is given, in particular, they emphasize the priority importance of mechanisms of state and public administration for general secondary education at the present stage of development of a democratic society. The mechanisms of state and public administration and local self-government of the education department are considered, functions of which are carried out in different conditions of small towns of Ukraine (towns of oblast and rayon significance, urban OTG); the terminology analysis of the frequency of hits of Internet users to the main concepts of the chosen topic is given; the phenomenon of state and public administration for the development of general secondary education is 
considered, as well as author's views on involving the public in the implementation of educational policy, the formation of competencies not only of managerial personnel of institutions and educational institutions, but also leaders of public organizations for work in conditions of state and public administration.

The author convinces that the proposed form of management should be aimed at creating a qualitative innovative educational space for the development of general secondary education and moral values, trust in small towns of Ukraine. The mechanism for their implementation should cover all structures: school, business, community as a whole. At the same time, educational institutions may have different readiness to implement mechanisms of state and public administration, and therefore proposes to systematically analyze the progress of implementation of state and public administration according to certain indicators. It points out that an important mechanism of state and public administration of the department of education for the development of ZSO may be the mechanism of project management, it is important that they are innovative in nature and ensure the development of all administrative structures and various spheres of life of the community of the city; observes that successful implementation of the projects requires both competent management and public control over their implementation, and a combination of mechanisms for influencing human development as an individual, and its socialization in the educational educational space becomes a sign of partnership.

Key words: management, mechanism, local government, phenomenon, small cities, department of education, trust.

Модернізація сучасної системи управління, перехід іï від державної адміністративно-командної форми минулої радянської доби до державногромадської форми управління в загальній середній освіті й у загальноосвітньому навчальному закладі та до громадсько-державної форми управління за умов реформування $є$ його стратегічними завданнями.

У процесі реалізації таких завдань, за умов внесення трансформаційних змін у багатовимірне суспільство виникла принципово нова ситуація - втрата державою монополії на певні складові функціонування й управління, відкриття навчальних закладів, зокрема приватної форми власності та конфесійної приналежності, створення інституцій громадянського суспільства, залучення міжнародних організацій тощо.

На основі аналізу наукових праць з'ясовано, що процес системних змін як у суспільстві, державі, так і сфері освіти, у тому числі загальної середньої, детермінує характер зміни цілей, завдань, функцій, форм управління. Варто зазначити, що сфера загальної середньої освіти потребує такої форми управління, яка сприяла б, насамперед, досягненню цілей i 
розв'язанню завдань державної освітньої політики, наданню права на автономність у діяльності закладів освіти, забезпечила б рівні умови для громадян у здобутті 3СО, а також iї якості. При цьому важливим $\epsilon$ впровадження відповідних ефективно діючих механізмів управління.

У науковому дискурсі висвітлюються різні підходи щодо вирішення проблеми створення та практичної реалізації механізмів державного, державно-громадського управління системою освіти, зокрема загальною середньою. Цим питанням присвятили свої дослідження такі сучасні вчені, як: М. Білинська, Р. Вдовиченко, Л. Гаєвська, В. Грабовський, Д. Двінчук, Л. Калініна, В. Кремень, В. Луговий, Т. Лукіна, А. Мазак, І. Осадчий, С. Шевченко та ін. Важливість наукових доробків полягає в тому, що вчені розглядають механізми управління системою освіти, враховуючи при цьому соціальне замовлення, результати організації діяльності науковоосвітніх структур, громадських рад, напрями консолідації зусиль різних осіб та громадських організацій, зацікавлених у розвитку $3 \mathrm{CO}$, генезис взаємодії держави, педагогічної громадськості й соціуму тощо.

У наукових роботах «Державно-громадське управління загальною середньою освітою на районному рівні» (2006), «Механізми державного управління розвитком загальної середньої освіти в Україні» (2012) учені В. Грабовський, Л. Паращенко аналізують зовнішні державні й громадські механізми як окремі системи, внутрішні механізми (моніторинг, громадське опитування, волонтерські акції, використання соціальних індикаторів, розвиток партнерських відносин тощо), які виконують роль спеціальних засобів для приведення цих систем у дію [4; 10]. Важливою для представників сфери освіти є монографія «Теоретико-методичні засади інформаційного забезпечення організаційного механізму управління загальноосвітнім навчальним закладом», автором якої є вчена Л. Калініна (2014). У науковій праці розкрито систему науково-обгрунтованих і дієвих організаційних механізмів управління закладом освіти як специфічної сфери управлінської діяльності, інформаційного менеджменту та практики управління сферою освіти цифрової доби, а також їх методологічні та теоретичні основи як наукового феномена й об'єкта дослідження в теорії та методиці управління освітою [7]. Враховуючи зміст опрацьованих наукових джерел, переконалися, що створити механізми державногромадського управління нелегко й наведені вище міркування лише підтверджують актуальність проблеми розгляду.

Мета статті та завдання дослідження - розкрити пріоритетне значення механізмів державно-громадського управління загальною середньою освітою для розуміння незворотності реформування та модернізації загальної середньої освіти й управління нею на сучасному етапі розвитку громадянського суспільства.

Доцільно насамперед зупинитися на розкритті сутності поняття «механізм». У Великому тлумачному словнику знайдено таку 
характеристику: «внутрішня будова, система чого-небудь» [3, с. 523]. Учений О. Конт 3 метою пояснення цілісності й життєздатності суспільства як «соціального тіла» визначає його як соціальний механізм, а Т. Франчук додає, що кожне суспільство має свій соціальний механізм, який забезпечує його виживання й розвиток [8; 15]. За твердженням учених, «державний механізм» розглядається як система здійснення державної влади за допомогою сукупності державних органів та установ, а «соціальний механізм суспільства» - як відносно стійка, стабільна система елементів і зв'язків, що забезпечують функціонування й розвиток суспільства $[1 ; 2 ; 6]$.

Оскільки об'єктом нашого дослідження є відділ освіти малих міст (міст обласного та районного значення, міських ОТГ), то будемо розглядати його механізми державно-громадського управління. Цей виконавчий орган утворюється міською радою та $\epsilon$ підзвітним i підконтрольним ій i виконує одночасно делеговані державою йому повноваження. Особливість цієї структури полягає в тому, що вона становить інтегрований адміністративно-організаційний механізм: діяльність міського відділу освіти базується на основі повноважень, делегованих міським виконавчим комітетом та державою. Феномен механізму управління ЗСО для такої структури полягає ще й в тому, що в ньому поєднуються функції держави, місцевої влади та громадськості. Вважаємо, що в умовах малих міст обласного значення та міських ОТГ запровадити механізми державно-громадського управління 3 організаційної точки зору можна легшим шляхом, ніж в умовах міст районного значення. Адже сам міський відділ освіти уже реалізує механізм управління ЗСО «знизу догори» (самоврядне управління), з одного боку, а 3 іншого, можуть спостерігатися й труднощі у створенні інноваційної моделі ЗСО в міських ОТГ. Насамперед суть їх (труднощів) зводиться до того, що йде процес оновлення управлінських структур, запровадження нової виборної системи не завжди може привести до партнерської взаємодії суб'єктів обраної самоврядної влади, компетентного керівництва міською громадою. Разом із тим, аналіз досвіду державно-громадського управління відділу міської ОТГ засвідчує, що поки що громадськість недостатньо компетентна 3 питань демократизації управління системою освіти й менеджменту, що може ускладнювати ії участь у цьому процесі. У зв'язку із цим виникає потреба в науковому обгрунтуванні змісту державно-громадського управління розвитком ЗСО, з'ясуванні феномену механізмів взаємодії місцевих органів управління й громадських структур, сутність якого у Великому тлумачному словнику сучасної української мови розглядається «як рідкісне, незвичайне, виняткове явище» [3].

У науковій сфері ситуація складається так, що сутність понять «механізми державно-громадського управління розвитком загальної середньої освіти» все більше цікавить науковців, дослідників, філософів, 
соціологів, психологів, педагогів, тобто зростає інтерес до інтегрувальних процесів у суспільстві. Нами було проведено термінологічний аналіз частоти звернень користувачів мережі Інтернет до цих понять. Для цього було розділено терміни на дві групи: базові й похідні: до групи базових віднесено «механізм / механізми», «механізм / механізми управління»: до групи похідних - «механізм державно-громадського управління ЗСО», «механізм державно-громадського управління розвитком ЗСО», «механізм державно-громадського управління якістю освіти». У таблиці 1 представимо результати пояснення терміну «механізм», здійсненого у червні 2009 р. та грудні 2017 р.

Таблиия 1

\begin{tabular}{|c|c|c|c|c|c|c|c|c|c|}
\hline \multirow{3}{*}{ № } & \multirow{3}{*}{$\begin{array}{l}\text { Мова } \\
\text { запиту }\end{array}$} & \multirow{3}{*}{$\begin{array}{c}\text { Назва } \\
\text { терміну }\end{array}$} & \multirow{3}{*}{$\begin{array}{l}\text { Форма } \\
\text { запиту }\end{array}$} & \multicolumn{6}{|c|}{$\begin{array}{c}\text { Результати пошуку } \\
\text { (тисяч документів/сторінок) }\end{array}$} \\
\hline & & & & \multicolumn{3}{|c|}{ Червень 2009} & \multicolumn{3}{|c|}{ Грудень 2017} \\
\hline & & & & $\begin{array}{l}0 \\
00 \\
8 \\
0 \\
0 \\
0\end{array}$ & $\underset{\ddot{\theta}}{\stackrel{0}{\pi}}$ & 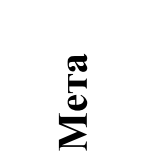 & $\begin{array}{l}\frac{0}{60} \\
\dot{0} \\
\dot{0}\end{array}$ & $\underset{\ddot{\theta}}{\ddot{\theta}}$ & 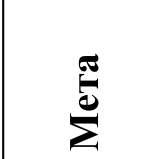 \\
\hline 1 & Укр. & Механізм & $\begin{array}{c}\text { «без } \\
\text { лапок» }\end{array}$ & 5530000 & 3480000 & 174000 & 3920000 & 290000 & 3790000 \\
\hline 2 & Укр. & $\begin{array}{c}\text { Механізм } \\
\text { управл. }\end{array}$ & $\begin{array}{c}\text { «без } \\
\text { лапок» }\end{array}$ & 5410000 & 323000 & 138000 & 2140000 & 54300 & 299000 \\
\hline 3 & Укр. & $\begin{array}{c}\text { Механізм } \\
\text { управління } \\
\text { якістю } \\
\text { освіти } \\
\end{array}$ & $\begin{array}{c}\text { «без } \\
\text { лапок» }\end{array}$ & 211000 & 28000 & 96000 & 594000 & 33000 & 264000 \\
\hline 4 & Укр. & $\begin{array}{c}\text { Механізм } \\
\text { ДГу }\end{array}$ & $\begin{array}{c}\text { «без } \\
\text { лапок» }\end{array}$ & 446000 & 30000 & 54600 & 848000 & 23100 & 143000 \\
\hline 5 & Укр. & \begin{tabular}{|} 
Механізм \\
ДГУ \\
розвитком \\
ЗСО \\
\end{tabular} & $\begin{array}{c}\text { «без } \\
\text { лапок» }\end{array}$ & 162000 & 16000 & 10500 & 183000 & 26600 & 26900 \\
\hline 6 & Укр. & $\begin{array}{c}\text { Механізм } \\
\text { ДГУ } \\
\text { якістю } \\
\text { освіти }\end{array}$ & $\begin{array}{c}\text { «без } \\
\text { лапок» }\end{array}$ & 49300 & 5050 & 11700 & 37600 & 6880 & 13500 \\
\hline
\end{tabular}

Пошук терміну «механізм» за ключовими словами без «лапок», контент-аналіз назв і змісту більшості документів у різних українських IПС дозволяс зробити висновки про те, що накопичено теоретичні знання щодо феномена механізму, який активно вивчається й використовується 
вченими та практиками в науковому обігу різних галузей наук. За ключовими словами термін «механізм державно-громадського управління розвитком ЗСО, iї якості» українською мовою широко репрезентовано в Інтернеті (удвічі більше у 2017 році в порівнянні з 2009 роком).

Для більш повного висвітлення обраної теми подамо перелік механізмів державної та громадської форм управління. Учений В. Корженко класифікував механізми державного управління i, на його думку, домінуючою рисою адміністративного механізму державного управління $\epsilon$ застосування елементів авторитарного типу взаємин між суб' єктом і об' єктом управління; економічний механізм дещо відрізняється від державного, суть його полягає в тому, що він не примушує й не забороняє виконувати певні дії, тобто дає свободу вибору; інформаційнопсихологічний механізм так само сприяє вибору й інформує про різні аспекти економічної діяльності, наукові досягнення, негативні чи позитивні наслідки певних дій. Важливо, що держава, використовуючи інформаційно-психологічний механізм, матеріальну винагороду чи покарання на себе не бере, як це відбувається при застосуванні економічного механізму [9].

У період децентралізації, дебюрократизації, реформування ЗСО виникає потреба в запровадженні нових механізмів управління іiі розвитком. Кожна ii складова була, $\epsilon$ i буде державним пріоритетом, основою соціального, політичного, економічного, духовного й культурного розвитку спільноти. Іншими словами, ЗСО $є$ як державним, так i громадським інститутом, управлінська діяльність якого має базуватися на інноваційних механізмах - феноменах модернізації державно-громадського управління загальною середньою освітою, тому що на державу й на суспільство однаково, на нашу думку, покладено відповідальність за іiі розвиток. Із одного боку, це зумовлено тим, що сама система ЗСО уже $\epsilon$ механізмом самоорганізації й покликана забезпечувати життєдіяльність соціальної системи, змінюючи при цьому спосіб висвітлення інформації, набутого досвіду, культури й цінностей, одночасно впливає на розвиток соціуму, стає головним засобом запровадження змін, які не порушують структури економічного фундаменту системи. Інвестиції в ЗСО відіграють важливу роль в економічному й соціальному прогресі: iснує пряма залежність між рівнем освіти та продуктивністю праці людини. Із другого боку, ЗСО як самоорганізована система, здатна пристосовуватися до постійних змін, реагуючи на виклики часу, вимагає переходу від традиційної моделі, що базується на пріоритеті простого засвоєння й відтворення інформації, до освітньої моделі як засобу всебічного розвитку та задоволення потреб особистості, тобто освіта стає товаром, а не залишається лише державною або суспільною справою.

Отже, нові відносини, зумовлені суспільними, політичними, 
економічними, культурними змінами, глобалізаційними процесами, інформатизацією, вимагають інших механізмів та форм управління розвитком 3СО, які б відповідали і принципам демократії, i ринковим відносинам. Модернізація управлінських механізмів у такому випадку стане важливим засобом розвитку освіти в Україні взагалі, а в малих містах зокрема. Запровадити нові підходи до управління розвитком ЗСО здійснити іiі реформування, модернізацію - нелегко на сучасному етапі, тим більше перейти на державно-громадське, самоврядне управління розвитком ЗСО. Погоджуємося із думкою вченої Н. Протасової про те, що необхідно подолати деякі суперечності, які породжені трансформаційними процесами українського суспільства. До них, як стверджує науковець, варто насамперед віднести: суперечність між усталеним стереотипом мислення про монополію держави в управлінні освітніми установами й задекларованою в нормативних документах новою паритетною роллю суспільства в управлінні ними; між застарілою матеріально-технічною базою, недостатнім фінансуванням освітньої галузі та необхідністю забезпечення високої якості освіти, задоволенням освітніх потреб соціальних замовників; між необхідністю збереження стабільності у функціонуванні галузі освіти й об'єктивною потребою іiї демократизації та модернізації; між потребою збереження єдиної загальнодержавної системи управління освітою та необхідністю наближення iі до національнорегіональних особливостей, їхніх управлінських структур. Таким чином, державно-громадське та самоврядне управління освітою в інтересах людини, суспільства, держави передбачає їх оптимальну взаємодію [6].

Учена Л. Паращенко розглядає державно-громадське управління як механізм державного управління ЗСО [10, с. 292], одночасно вказує, що, реально оцінивши ситуацію, заклади освіти можуть мати різну готовність до реалізації цього механізму, а тому пропонує систематично аналізувати хід упровадження державно-громадського управління за певними показниками. По-перше, «ЗНЗ, у яких відповідно до зареєстрованого статуту буде створений i функціонуватиме орган самоврядування, діяльність якого базуватиметься на демократичних, державно-громадських засадах, матиме комплекс управлінських повноважень, у тому числі, iз ухвалення рішень про розподіл фонду оплати праці, у \%; публічно звітуватиме про освітню й фінансово-господарську діяльність, у \%; матиме власні сайти в мережі Інтернет і регулярно оновлюватиме їх. По-друге, громадські організації, у яких буде створено орган управління, діяльність якого базуватиметься так само на демократичних, державно-громадських засадах управління освітою». Що важливо, за пропозицією вченої, «цей орган повинен мати повноваження з розподілу бюджетів ЗНЗ та фонду стимулювання їх керівників, у \%. По-третє, у таких закладах ліцензування й атестація проводитимуться комісіями із залученням представників громадськості з числа осіб, що не є працівниками установ, підвідомчих 
органам управління освітою, у \%» [10, с. 242]. Для впровадження в практику такого механізму науковець пропонує критерії:

- наявність якісної нормативно-правової бази;

- системи ДГУ у ЗНЗ, які братимуть участь у розподілі фонду оплати праці педагогів;

- частка місцевих організацій, у яких створені органи ДГУ, що братимуть участь у розподілі бюджетів ЗНЗ та фонду оплати праці керівників 3Н3;

- у участь громадськості в управлінській діяльності відділу освіти та ЗН3;

- залучення громадськості до зміцнення матеріально-технічної бази;

- участь батьків i учнів в обговоренні питань та ухваленні управлінських рішень;

- наявність дискусійних майданчиків для обговорення актуальних проблем і вирішення конфліктів;

- поінформованість суб'єктів освітнього процесу й громадськості про діяльність органів ДГУ;

- вплив діяльності органів ДГУ на підвищення якості освіти (виховні ефекти, вплив на якість навчання, створення сприятливих умов в освітній установі тощо);

- наявність моніторингу діяльності органів ДГУ.

Учений О. Пастовенський у дисертації «Громадсько-державне управління загальною середньою освітою в регіоні» (2015) обгрунтував теоретико-методологічні засади громадсько-державного управління загальною середньою освітою в регіоні, розробив авторську модель системи реалізації досліджуваного феномену [11]. Учений визначив і науково обгрунтував функції громадсько-державного управління 3СО, які можуть переходити в механізми. Треба зазначити, що вони мають носити характер не традиційний, не усталений попереднім управлінським досвідом, а набувати нового змісту, наповнюватися інноваційними управлінськими практиками, що зможуть забезпечувати інші засади взаємодії органів влади й громади. Таким чином з'явиться нова якість державно-громадського управління, при якій саме держава ініціюватиме створення таких умов для діяльності громади, за яких іï представники зможуть впевнено брати участь у виробленні стратегії та тактики управління розвитком $3 \mathrm{CO}$, у реалізації міських освітніх програм, проектів, підтримці творчо обдарованих дітей, вносити пропозиції щодо реформування та модернізації 3СО, здійснювати громадський контроль за рівнем якості освіти, матеріально-технічним забезпеченням закладів освіти, станом фінансових потоків та їх використанням у місті.

Розглянемо феномен механізмів за джерелом, автором якого $\epsilon$ О. Пастовенський [11] (див. табл. 2). 
Таблиия 2

\section{Феномен механізмів державно-громадського управління}

\begin{tabular}{|c|c|c|}
\hline $\begin{array}{c}\text { Механізми державного } \\
\text { управління }\end{array}$ & $\begin{array}{l}\text { Механізми громадсько- } \\
\text { державного управління }\end{array}$ & Феномен механізмів ДГУ \\
\hline $\begin{array}{c}\text { Механізм розвитку } \\
\text { персоналу і вчителів }\end{array}$ & $\begin{array}{c}\text { Механізм інформаційно- } \\
\text { діагностичний }\end{array}$ & Як механізм \\
\hline $\begin{array}{c}\text { Механізм розвитку } \\
\text { навчального середовища }\end{array}$ & $\begin{array}{c}\text { Механізм організаційно- } \\
\text { координаційний }\end{array}$ & $\begin{array}{l}\text { Широка контекстуальна } \\
\text { репрезентація в Інтернеті. }\end{array}$ \\
\hline $\begin{array}{c}\text { Механізм розвитку } \\
\text { курикулуму } \\
\text { (знаннє-забезпечення) }\end{array}$ & $\begin{array}{l}\text { інтегрувально- } \\
\text { моделювальний }\end{array}$ & Трипоєднаність \\
\hline $\begin{array}{c}\text { Механізм розвитку } \\
\text { менеджменту / } \\
\text { фінансування освіти }\end{array}$ & контрольно-експертний & $\begin{array}{c}\text { Найвища ефективність на } \\
\text { засадах довіри }\end{array}$ \\
\hline $\begin{array}{c}\text { Механізм оцінювання } \\
\text { розвитку освіти }\end{array}$ & $\begin{array}{l}\text { координаційно- } \\
\text { коригувальний }\end{array}$ & Нова якість управління \\
\hline $\begin{array}{l}\text { Механізм розвитку } \\
\text { цілевизначення та } \\
\text { освітньої політики }\end{array}$ & $\begin{array}{c}\text { Оптимізації навчальних } \\
\text { закладів }\end{array}$ & $\begin{array}{c}\text { Відповідність } \\
\text { європейським нормам }\end{array}$ \\
\hline & & Конструктивний діалог \\
\hline
\end{tabular}

Як бачимо, роль і функції держави із запровадженням державногромадського чи громадсько-державного управління в нових соціальноекономічних умовах набувають більшого значення, адже становлення та перспективи розвитку соціальної відповідальності держави залежать від можливостей формування феномену механізму державно-громадського управління. Варто зауважити, що за таких умов може сформуватися довіра до соціальних інститутів, стійкий соціальний феномен, а також забезпечуватиметься впровадження європейських норм відкритого для громадян суспільства. На наш погляд, залучення громад до реалізації освітньої політики малого міста підсилять самоврядні структури (з'явиться впевненість у необхідності їхньоі участі в управлінні розвитком ЗСО, механізмі впливу на зміни в громаді, сильній «вертикалі», збудованій з низу до верху). Тобто виникає закономірність: сильна громада - сильне громадянське суспільство.

Одним із важливих механізмів ДГУ відділу освіти розвитком ЗСО може бути механізм управління проектами як цілеспрямованою зміною, обмеженою в часі, окремої системи з установленими вимогами до якості результатів, можливими рамками витрат засобів і ресурсів, із специфічною організацією. Важливо, щоб вони мали інноваційний характер i забезпечували розвиток усіх управлінських структур та різних сфер життєдіяльності громади міста. Із метою формування особистості та загальнолюдських i національних цінностей у молодого покоління необхідно втілювати в практику управління малого міста на засадах довіри 
та партнерства різні проекти, до впровадження яких залучатимуться представники органів влади та міських органів самоврядування. Принагідно зауважимо, що для успішної реалізації проектів потрібно як компетентне керівництво, так і громадський контроль.

Варто проаналізувати ті механізми, які б розкривали сутність явища: феномен механізмів ДГУ розвитком 3 СО в малих містах України. Враховуючи нові умови та стратегї розвитку ЗСО, маємо розробити таку систему механізмів, яка б забезпечила реалізацію завдань, поставлених перед державно-громадським управлінням відділу освіти малого міста. На нашу думку, для свідомого сприйняття та впровадження державногромадського управління в освіті, насамперед у відділі освіти, потрібні працівники 3 новим мисленням, готові реагувати на виклики демократичного громадянського суспільства, оперативно приймати рішення, компетентно вирішувати проблеми громади міста. А також необхідно розробити комплексну програму професійного зростання працівників, що сприятиме формуванню компетентностей управлінських кадрів до роботи в умовах державно-громадського управління ЗСО. Одночасно забезпечити якісну підготовку представників громадських структур до участі в управлінні 3СО, делегувати повноваження таким чином, щоб рівень складності завдань, які їм доводиться розв'язувати, відповідав рівню їхньої управлінської культури. А для цього варто створити міську школу - Школу безперервного навчання керівних кадрів, форма ï - очно-дистанційна; представники громадських об'єднань та представники влади зможуть навчатися демократичним формам управління, методам партнерства, співуправління, основам розвитку ЗСО в контексті нових законодавчих актів. Завдання такої Школи: формування компетентностей із питань державно-громадського управління розвитком ЗСО та громадського самоврядування; створення «інтелектуальноемоційного клімату» для плідної співпраці представників органів місцевої влади та громадськості; ознайомлення із інноваційними педагогічними технологіями; вирішення проблем щодо оновлення й модернізації змісту 3СО; забезпечення обміну досвідом роботи, пропаганди перспективних моделей інноваційних практик. Окрім цього, через діяльність такої Школи доцільно запровадити механізм створення єдиного освітнього простору як чинника розвитку $3 \mathrm{CO}$ в малому місті, суть якого полягатиме в забезпеченні педагогічно доцільного простору життєдіяльності, який сприятиме розвитку інноваційного ресурсу особистості; створюватиме інтегрований засіб накопичення та реалізації інноваційного потенціалу освітніх установ та закладів. Такий простір малого міста можемо розглядати як відкриту й активну соціальну сферу функціонування й розвитку системи загальної середньої освіти, у якій діятиме комфортна атмосфера для формування особистості й враховуватимуться умови 
громади (демографічні, екологічні, соціально-економічні, політичні та ін.), потреби соціальних замовників (і самої особи), реалізовуватимуться освітні послуги установами освіти й організаціями, яким властивий виховний і розвивальний потенціал.

Забезпечити якісний інноваційний освітній простір щодо розвитку ЗСО в малих містах при державно-громадському управлінні можна, на наше переконання, за умови відновлення довіри до соціальних інститутів, формування феномену загальної довіри в громаді міста. Поняття «довіра» тісно пов'язане із «відповідальністю», «відкритістю», «чесністю» та іншими загальнолюдськими цінностями. Тут важливу роль відіграватиме загальна середня освіта, зокрема школа, яка допоможе знайти таку форму спілкування між представниками державних і громадських структур, яка могла б забезпечувати співпрацю на довірчих засадах. Вважаємо, таке співробітництво може забезпечити відкритий діалог, ініційований представниками як державних, так і громадських інституцій. На жаль, довіра, відповідальність, чесність, відкритість не стали поки що домінуючими, усвідомленими цінностями громадян. Нами з'ясовано, що довіра - явище давнє, саме становлення іiі теорії відбувалося поступово, тривало впродовж усієї еволюції філософської, соціальної, економічної, психологічної, політичної, педагогічної думки.

Прикладом формування довіри в громадах може слугувати сучасна демократична європейська модель державно-громадського управління, яка базується на концепції соціальної держави, основними цінностями якої $є$ свобода, рівність шансів і відсутність дискримінації, солідарність і соціальна згуртованість, соціальний діалог i розвинене громадянське суспільство, соціальна відповідальність і довіра. Варто зауважити, що при низькому рівні довіри до відділу освіти та закладів освіти демократизація управління ними гальмується.

Для подолання суперечностей у розвитку громад, формуванні сучасної моделі державно-громадського управління 3СО, на нашу думку, варто взяти за основу комплексний підхід до втілення в життя базових цінностей довіри. Механізм упровадження повинен охопити всі структури: органи управління, бізнес, громаду в цілому. У період сучасних викликів важливу роль можуть відіграти реформи, розпочаті в країні, ефективність проведення яких залежить від сформованої довіри до органів влади та органів місцевого самоврядування. Тому представники громадськості повинні набути управлінських навичок, умінь громадського контролю, що, у свою чергу, забезпечить реформування державного управління на демократичних засадах, а також призведе до відкритості його для членів територіальних громад. Важливу роль у реалізації цих завдань відіграє освіта, яка входить до складу так званого «класичного не трикутника, а чотирикутника (учні - батьки - заклад освіти - громада)», що покликаний 
забезпечити соціальне партнерство між органами влади, самоврядування, громадами та освітою. Завдання це, звичайно, надскладне, але конче необхідне для формування особистості-Людини, гідної довіри, та громади, у якій сповідуватимуться моральні цінності.

Виходячи з викладеного вище, можна зробити такі висновки:

Формування в людини загальнолюдських цінностей (довіри, відповідальності, чесності, відкритості) мають забезпечувати і державні інститути, і громадські об'єднання в тісній співпраці. Іншими словами, таке поєднання механізмів впливу на розвиток людини як особистості, iii соціалізацію в інноваційному освітньому просторі набуває ознак партнерства, що можна віднести до феномену механізму державногромадського управління розвитком ЗСО - взаємовигідних стосунків між державними, громадськими організаціями, бізнесовими структурами для спільного вирішення нагальних проблем розвитку освіти в малому місті.

Для успішного впровадження державно-громадського управління у відділі освіти та закладах освіти потрібні працівники з новим мисленням, готові реагувати на виклики громадянського суспільства, оперативно приймати рішення, компетентно вирішувати проблеми шкільної освіти та громади міста, а тому необхідні механізми, які були б спрямовані на професійне зростання працівників, формування в них компетентностей до управлінської діяльності в нових умовах - реформування та модернізації загальної середньої освіти. Одночасно виникає потреба в механізмах щодо забезпечення підготовки і представників громадських структур до участі в управлінні ЗСО. Ці питання на сьогодні залишаються актуальними і для нових досліджень, і для вирішення їх на практиці.

\section{СПИСОК ВИКОРИСТАНИХ ДЖЕРЕЛ}

1. Бакуменко В. Д. Державне управління i державно-управлінські рішення: вступ до досліджень / В. Д. Бакуменко // Вісник УАДУ. 1999. - № 4. - С. 68-79.

2. Бова А. Соціальний капітал в Україні: досвід емпіричного дослідження / А. Бова // Економічний часопис - XXI. - 2003. - № 5. C. $46-50$.

3. Великий тлумачний словник сучасної української мови / уклад. і гол. ред. В. Т. Бусел. - Ірпінь : ВТФ «Перун», 2004. - 1440 с.

4. Грабовський В. А. Державно-громадське управління загальною середньою освітою на районному рівні : дис. ... канд. наук. / В. А. Грабовський. - К., 2006. -233 с.

5. Дейч М. С. Становлення та розвиток багаторівневої соціальної відповідальності: управлінський аспект : монографія / М. С. Дейч ; НАН України, Ін-т економіки промисловості. - Донецьк, 2014. - 352 с.

6. Державне управління в Україні: централізація і децентралізація : 
монографія / відп. ред. Н. Р. Нижник ; кол. авт.: В. Б. Авер'янов, І. А. Грицяк, С. Д. Дубенко [та ін.]. - К. : Вид-во УАДУ, 1997. - 448 с.

7. Калініна Л. М. Управління новою українською школою / Л. М. Калініна // Директор школи. - 2017. - № 1-2(793-794), січень. C. $12-21$.

8. Конт О. Загальний огляд позитивізму / О. Конт ; пер. 3 фр. І. А. Шапіро ; під ред. Е. Л. Радлова. - 2-е вид-во. - М. : ЛИБРОКОМ, 2011.

9. Корженко В. В. Категорії «державний механізм управління» та «механізм державного управління»: порівняльний аналіз / В. В. Корженко, Т. М. Лозинська // Теорія та практика державного управління : зб. наук пр. - Х. : Вид-во ХарРІ НАДУ «Магістр», 2008. Вип. 2(21). - С. 16-24.

10. Паращенко Л. І. Механізми державного управління розвитком загальної середньої освіти в Україні : дис. ... д-ра наук з держ. упр. / Л. І. Паращенко. - К., 2012. - 449 с.

11. Пастовенський О.В. Громадсько-державне управління загальною середньою освітою в регіоні : дис. ... д-ра пед. наук / О. В. Пастовенський. - Київ, 2015. - 438 с.

12. Реформування освіти в Україні: державно-управлінський аспект : навч.-наук. вид. / Н. Г. Протасова, В. І. Луговий, Ю. О. Молчанова та ін. ; за заг. ред. Н. Г. Протасової. - Львів : НАДУ, 2012. - 456 с.

13. Рогова В.Б. Упровадження державно-громадського управління у закладах системи середньої освіти [Електронний ресурс] / В. Б. Рогова. - Режим доступу до журн. : http://www.narodnaosvita. kiev.ua/vupysku/3/ statti/3rogova/ rogova.htm.

14. Савченко I. Д. Довіра як міждисциплінарне поняття / І. Д. Савченко // Педагогічні науки: теорія, історія, інноваційні технології. - 2011. № 18.

15. Франчук Т. Й. Цілісний освітній простір: педагогічні основи його формування : монографія / Т. Й. Франчук. - Кам'янець-Подільський : Кам'янець-Поділ. нац. ун-т ім. І. Огієнка, 2009. - 244 с. 